\title{
NARASI ISLAMISME DAN PESANTREN: POLA PENOLAKAN ISLAM POLITIK DI PONDOK PESANTREN GONTOR PONOROGO
}

\author{
Herlambang Andi Prasetyo Aji \\ Pasca Sarjana Interdisciplinary Islamic Studies, UIN Sunan Kalijaga \\ Jl. Laksda Adisucipto, Papringan, Caturtunggal, Kec. Depok, Kab. Sleman, \\ Yogyakarta 55281 \\ E-mail: Herlambangandi29@gmail.com
}

Abstract: The polemic between religion and the nation-state is very recurrent and has the potential to strengthen when there are some critical changes in the political landscape. This case is reinforced by the results of a survey with the theme of scholars and nation-states, which reached 71.56 percent of scholars who received and 16.44 percent of scholars who rejected nation-states with different backgrounds. The purpose of this study is to explain the narrative of Islamism and its patterns of rejection in Pondok Modern Darussalam Gontor. The research method used is ethnographic in the sense of understanding the practice and life of individuals as part of a wider community and scope, with research subjects being religious scholars who are people with a formal religious education background in Pondok Modern Darussalam Gontor. The results showed that in facing the narrative of Islamism, the people of Pondok Modern Darusalam Gontor used a puritanical (puritanical moderate Islam) discourse of Islam with the perspective of political Islamization. Political Islamization does not mean that it wants to break down the ideology of the Unitary Republic of Indonesia, but rather still accepts the concept of the NKRI nation-state, including the ideology of Pancasila, only to clarify the basis and objectives following Islam by being semi-rejectionist towards a controversial interpretation of government.

Keywords: Islamism, Pesantren, $\mathrm{N}$ ation-State

A bstrak: Polemik yang terjadi antara agama dan negara-bangsa sangat recurrent dan berpotensi menguat ketika terjadi beberapa perubahan penting dalam lanskap politik. Hal ini diperkuat dengan hasil survei dengan tema ulama dan negara bangsa yang mencapai angka 71,56 persen ulama yang menerima dan 16,44 persen ulama yang menolak negara-bangsa 
dengan latar belakang berbeda. Tujuan penelitian ini adalah untuk menjelaskan narasi Islamisme dan pola penolakannya di Pondok Modern Darussalam Gontor. M etode penelitian yang digunakan adalah etnografis dalam pengertian untuk memahami praktik serta kehidupan individu sebagai bagian dari komunitas serta cangkupan yang lebih luas, dengan subjek penelitian adalah religious scholar yang merupakan orang-orang yang berlatar belakang pendidikan agama secara formal di Pondok Modern Darussalam Gontor. Hasil penelitian menunjukan bahwa dalam menghadapi narasi Islamisme masyarakat Pondok Modern Darusalam Gontor menggunakan wacana Islam moderat puritan (puritanical moderat Islam) aksepsionis dengan kacamata Islamisasi politik. Islamisasi politik bukan berarti ingin merobohkan ideologi NKRI, tetapi tetap menerima konsep negara-bangsa NKRI, termasuk ideologi Pancasila, hanya saja lebih memperjelas dasar dan tujuan-tujuan yang sesuai dengan Islam dengan bersikap semi-rejeksionis terhadap interpretasi pemerintah yang kontroversial.

Kata K unci: Islamisme, Pesantren, Negara-Bangsa.

\section{A. PENDAHULUAN}

L engsernya pemerintahan Orde B aru pada bulan M ei tahun 1998 mengakibatkan sistem demokrasi semakin berkembang pesat dan ditandai dengan kebebasan pers, kebebasan berekspresi serta menyampaikan pendapat pribadi atau komunitas. Efek lainnya juga dapat membuka lebar pintu kebebasan dan partisi pasi politik termasuk transformasi sosial yang bahkan tidak pernah terjadi sebelumnya. Sistem demokrasi sudah membuka bermacammacam ruang publik sekaligus mempersiapkan panggung secara terbuka bagi aktor-aktor politik, sosial maupun keagamaan untuk memperbincangkan kembali formulasi kemaslahatan bangsa yang sampai saat ini sedang menghadapi konflik ekonomi dan politik.

Salah satu aktor yang mempunyai pengaruh cukup signifikan dalam kontestasi ini adalah tokoh-tokoh agama yang merupakan produk dari lulusan pondok pesantren. M ereka cukup aktif dalam proses mengoseptualisasikan kemaslahatan bangsa Indonesia melalui kerangka keagamaan dal am spektrum yang beragam. Diskursus keislaman yang menghiasi wilayah-wilayah periferal dalam isu-isu kebangsaan dan kenegaraan bergerak ke tengah dan menjadi idiom penting khususnya pada wilayah perdebatan sosial politik, terutama 
ketika narasi Islamisme mulai banyak menghiasi kontestasi serta perebutan otoritas politik dan keagamaan, terutama pada wilayah regional. M ayoritas kaum pendukung Islamisme secara tegas menolak paham sekularisme yang menyerukan pemisahan antara agama dengan politik (pemerintahan) ( $\mathrm{N}$ ashir, 2002: 154).

Polemik yang terjadi antara agama dan negara-bangsa, termasuk Islamisme, sangat recurrent dan berpotensi menguat ketika terjadi beberapa perubahan penting dalam lanskap politik. Hal ini diperkuat dengan hasil survei dengan tema ulama dan negara bangsa dalam sebuah penelitian yang dilakukan oleh Pusat Pengkajian I slam, Demokrasi, dan Perdamaian (PusPIDeP) U niversitas Islam N egri Sunan K alijaga di Yogyakarta. D ari hasil penelitian tersebut menggambarkan tentang konsep penerimaan dan penolakan ulama terhadap negara-bangsa. Ulama yang menerima konsep negara-bangsa tergolong tinggi, yaitu menunjukkan angka 71,56 persen. Sementara itu, mereka yang menolak berjumlah 16,44 persen. Dan sisanya tidak dapat diidentifikasi (Najib kailani \& Sunarwoto, 2019: 26). Dari hasil penelitian ini membuktikan bahwa masi $h$ terdapat beberapa pemuka agama khususnya Islam yang tidak setuju dengan konsep negara-bangsa dalam sistem demokrasi dan ini sekaligus menjadi menarik untuk diteliti mengenai dinamika cara menyikapi yang berbeda-beda terhadap konsep negara-bangsa. Terdapat faktorfaktor yang menyebabkan timbunya perbedaan-perbedaan sikap tersebut, baik dari segi sikap individual ulama yang secara subjektif, faktor sejarah, dan kebudayaan lokal di masing-masing kota yang tentunya hal ini menguatkan kepada munculnya politik identitas.

A da hal unik dari penelitian yang dilakukan oleh Pusat Pengkajian Islam, Demokrasi, dan Perdamaian (PusPIDeP) adalah meskipun peran organisasi keagamaan yang terbilang cukup besar seperti NU dan M uhammadiyah sangat signifikan di Indonesia, yaitu dari total 450 ulama yang telah disurvei terdapat 41,09 civil society yang menyatakan positif untuk berada di luar dua organisasi besar tersebut dan juga di luar dua minoritas di dalam islam seperti Syiah dan A hmadiyah (Najib kailani \& Sunarwoto, 2019 : 37). Tidak hanya itu, terdapat yang tidak memiliki kedekatan dengan lembaga keagamaan yang bersifat formal atau konvensional, atau memiliki hubungan yang sangat kuat dengan organisasi keagamaan. Hal ini juga menandakan bahwa potensi islamisme untuk muncul ke permukaan semakin kuat. 
Islamisme sendiri memiliki beberapa perbedaan dengan Islam yang sering diabaikan dan bahkan mulai hilang yang berimbas pada terciptanya keretakan antara umat beragama (K holiludin, 2016 : 45). K aum Islamisme menganggap seluruh rezim 'infidel' yang berkuasa di manapun berada sebagai musuh dekat (near enemy) dan musuh jauh (far enemy) (Peter M andaville, 2007). M enariknya adalah kelompok sosial maupun civil society dan sel uruh komponen yang ada di dalamnya terbilang yang paling rentan menerima narasi I slamisme dan positifnya pesantren, masjid, dan tokoh agama adalah beberapa komponen penting yang menjadi benteng pertahanan aktifitas narasi Islamisme di beberapa kota (Iman Fadhilah, Syaifuddin, R etno M awarini, 2016: 15).

B erangkat dari kegelisahan akademik yang bersumber dari hasil penelitian Pusat Pengkajian Islam, Demokrasi, dan Perdamaian (PusPIDeP) yang mencantumkan angka 16,44 persen ulama yang menolak konsep negarabangsa maka dugaan terhadap golongan Islamisme untuk mucul ke permukaan semakin kuat dengan berbagai macam ideologi. M aka peneliti memfokuskan penelitiannya di Pondok M odern Darussalam Gontor yang terletak di wilayah Ponorogo dengan alasan salah satu pondok dengan sistem kemodernan yang lebih terbuka. Pondok pesantren modern memiliki definisi yang menyelenggarakan mayoritas kegiatan pendidikannya dengan pendekatan modern melalui satuan pendidikan formal yang termasuk di dalamnya madrasah (Fithriah, 2018 : 16). Peneliti ingin melihat pola penerimaan dan penolakan Pondok M odern Darussalam Gontor dalam menghadapi wabah I slamisme yang didukung dengan terdapatnya sebagian ulama yang menolak sistem negara-bangsa.

Penelitian ini ingin menemukan sekaligus mengamati narasi-narasi Islamisme yang mulai berkembang di kalangan masyarakat dan lebih memfokuskan penelitiannya di wilayah pesantren yang berlokasi di Ponorogo dan bagaimana narasi itu mulai mempengaruhinya. K onsep dan narasi Islamisme dipilih oleh peneliti karena untuk mendeteksi pola suatu komunitas dalam merespons berbagai macam perkembangan yang bersifat kekinian untuk menggambarkan pola hubungan agama dan negara. D engan menggunakan konsep dan narasi ini maka peneliti akan lebih mudah dalam mengamati pola penerimaan dan penolakan konsep Islam politik di Pesantren Gontor. 


\section{B. ISLAM, POLITIK DAN BUDAYA INDONESIA}

Islam Politik atau yang biasa disebut Islamisme bukan suatu gerakan kembali kepada tradisi-tradisi yang telah mengalami perkembangan pada masa lalu yang memiliki keterkaitan dengan hubungan antara I slam dan politik dan di formulasikan oleh para fuqaha klasik (Najib K ailani \& Sunarwoto, 2019: 3). Tetapi Islamisme adalah suatu kumpulan fenomena dal am atmosfer sosial-politik yang dilakukan oleh sekelompok atau lebih individu muslim yang aktif melakukan berbagai macam aktivitas dan memiliki sistem nilai tertentu yang sudah mereka yakini (K epel, 2003 : 67). Islam Politik atau Islamisme adal ah sebuah gagasan baru yang mengubah hubungan formalistis dan simbolis yang terjadi antara I slam dan Politik menjadi tak terpisahkan dan terlihat sangat nyata. A nggota kaum Islamis berupaya menjadikan politik untuk selalu tunduk terhadap agama (N ajib kailani \& Sunarwoto, 2019: 3-4).

Dale Eickelman dan J ames Pisctori (1996) menjelaskan tentang kompleksitas definisi politik Islam yang mana mereka mendefinisikan sebagai politik yang diwarnai dengan sebuah persaingan (competition) dan tawar-menawar (bargaining) melalui interpretasi dan pemaknaan atas doktrin-doktrin, termasuk simbol-simbol keagamaan demi kepentingan mereka masingmasing. K ontestasi yang terbentuk telah melibatkan berbagai macam aktor, dari pelajar-pelajar sekolah di Prancis yang datang ke sekolah menggunakan jilbab, kaum intelektual dan para aktivis Islam memiliki latar belakang pendidikan tradisional dan barat, banyak orang yang telah terlibat dalam kegiatan dakwah dan layanan filantropi keislaman, termasuk juga kaum pejabat pemerintah yang memainkan berbagai jurus keagamaan dalam menjalankan kepentingan politik, birokrasi, administrasi masing-masing (Dale F. Eickelman, James Piscatori, 1996: 45).

Perlu untuk diketahui bahwasannya terdapat tiga unsur penting yang menjadi ciri khas dari Islamisme atau Islam politik yaitu: aktor, aktivisme, dan ideologi mereka. Pelaku yang terlibat secara langsung dalam semua unsur Islamisme adalah menggunakan agama I slam sebagai identitas utamanya. Ciri khas yang kedua adalah sikap aktivisme mereka yaitu semua aktivitas tindakan yang bernuansa politik dalam menjalankan kepentingan ideologi mereka (Noorhaidi Hasan, 2012).

Pada dasarnya yang menjadi ideologi dasar perpolitikan di Indonesia zaman Orla dan Orba adalah ideologi kebangsaan (N asionalisme). K ontestasi 
dan interaksi yang begitu sengit membuat pergeseran ideologi politik yang sangat beragam bentuknya kemudian dikembangkan oleh kelompokkelompok Islam di Indonesia. Seperti Islam moderat, mereka menjadika definisi demokrasi sebagai pondasi utama ideologi mereka dalam perpolitikan Islam di Indonesia. B erbeda dengan kelompok fundamentalis, mereka konsep 'negara Islam' sebagai pondasi utama mereka dalam bernegara. Sebagai sebuah fenomena yang recurrent terdapat perbedaan dalam jorgan gerakan para kaum fundamental, Hizbu Tahrir Indonesia (HTI) dan M ajlis M ujahidin Indonesia (M M I) misalnya, mereka mengusung konsep khilafah. Sementara itu Front Pembela Islam (FPI), mereka menggunakan konsep syari' ah, keluarga, dan masyarakat dengan laskar jihadnya yang terkenal. Perbedaan mendasar pada kelompok moderat dan puritas adalah mengenai paradigmanya. K elompok I slam moderat dalam hubungannya terhadap konsep agama dan negara-bangsa lebih condong pada paradigm simbiotik multukulturalistik. Sedangkan bagi para fundamentalis konsep berfikir mereka antara agama dan negara-bangsa lebih condong pada paradigma integrated sehingga menghasi lkan konsep dasar teokrasi (Basyir, 2016 : 359).

Islam politik seringkali muncul sebagai istilah penegasan diri demi memobilisasi civil society (kelas menengah) yang merasa termarginalkan oleh proses-proses ekonomi, politik, dan budaya. M asyarakat yang telah merasakan kegagalan modernitas kapitalis maupun utopis-sosialis kemudian mulai bergerak membuat istilah moralitas agama dengan mengharapkan pergantian sistem politik. Islam politik terkadang dapat dibaca sebagai cara kelas menengah M uslim yang baru tumbuh untuk menolak terhadap apa yang telah mereka anggap sebagai pengaruh asing, para elite nasional, sistem pemerintahan sekuler, dan para sekutu barat pemerintahan ( $N$ ajib kailani \& Sunarwoto, 2019 : 9). M ereka menolak keras "dominasi budaya barat", rasionalitas politik, sensibilitas moral, beserta simbol-simbol normatifnya, walaupun mereka sendiri memiliki bermacam-macam fitur dengan yang serba asing itu seperti : dasi, makanan, pendidikan, dan teknologi.

Definisi narasi peneliti meminjam istilah yang di gunakan oleh Halverson, G oodall \& Corman (2011) dalam bukunya berjudul M aster Narratives of Islamist Extremism. Dalam buku tersebut narasi merupakan beberapa gabungan cerita yang bersifat koheren dan digunakan untuk mendukung suatu tujuan dan ideologi tertentu yang memusatkan pada emosional dan kondisi para audiens. K onsep narasi biasanya mengandung unsur-unsur yang tidak 
diinginkan dan arahan-arahan tentang bagaimana mengatasi hal tersebut. $\mathrm{N}$ arasi ekstrim diidentikkan dengan penyebutan pembeda yang tegas atau antagonis antara pihak kawan dan lawan dan selalu menstigmatisasi pihak musuh dan sebaliknya memberikan kemuliaan terhadap pihak sendiri (selffulfilling prophecy) (Iman Fadhilah, Syaifuddin, R etno M awarini, 2016 : 19). $\mathrm{N}$ arasi sebagai fenomena recurrent juga mengadirkan kesan seperti suasana perang yang menuntut upaya eliminasi pihak lawan dengan berbagai macam cara, termasuk dengan cara kekerasan.

Definisi tentang Islam politik atau Islamisme juga diperkuat dengan dengan ekspresi politik-keagamaan yang terdiri dari empat unsur utama yang menyelimuti yaitu: militansi, radikalisme, ekstremisme, dan terorisme (N oorhaidi Hasan, 2012). D engan adanya unsur-unsur tersebut, I slamisme sudah bisa untuk dipastikan berbeda dengan Islam. B ahkan lebih dari itu, ia adalah sebuah ideologi untuk kepentingan proyek politik dengan mengatas namakan Islam.

\section{METODE PENELITIAN}

M etode penelitian yang digunakan adalah etnografis dalam pengertian untuk memahami praktik serta kehidupan individu sebagai bagian dari komunitas serta cangkupan yang lebih luas. Subjek penelitian ini terdiri dari masyarakat pondok pesantren Gontor yang terdiri dari asatidz yang berada di dalam pondok dan para alumni yang berada di luar pondok. Peneliti memilih kategori para asatidz yang termasuk para alumninya karena memiliki posisi penting, istimewa, dan kompeten dalam studi agama. K omponen ini seringkali bertindak sekaligus memiliki trendsetter untuk memperkenalkan gagasan, pola pemikiran, tren, kecenderungan dikalangan para sarjanawan muslim. A lasan peneliti memilih kaum muda adalah karena mayoritas memiliki ketidakjelasan serta ketidakmapanan status mereka maka dari itu, kaum muda berpotensi terdorong untuk menduduki ruang-ruang dal am proses interaksi sosial mereka dalam bermasyarakat dengan membawa slogan politik identitas mereka (Iman Fadhilah, Syaifuddin, Retno M awarini, 2016 : 20).

Dalam penelitian ini definisi para informan yang dipakai adalah religious scholar yang merupakan orang-orang yang berlatar belakang pendidikan agama secara formal yaitu para informan yang mengkaji dan mendalami teksteks keislaman secara khusus, termasuk yang melalui institusi pendidikan seperti pesantren, universitas Islam yang terkemuka di belahan dunia mana 
pun, seperti A I-A zhar, I bnu Saud, Tarim H adramaut, Institut A gama Islam N egri atau U niversitas Islam Negri yang ada di Indonesia, maupun yang mempelajari secara khusus mel alui tradisi majelis ta' lim yang terorganisi $r$ dan formal (Najib kailani \& Sunarwoto, 2019, p: 18-19). Para religious scholar ini biasanya memiliki pengetahuan keagamaan yang mendalam seperti di bidang fiqih, tauhid, tasawuf, atau pendidikan Islam lainnya. M aka dari itu peneliti memilih informan religious scholar yang telah Iulus dari Gontor karena mereka menguasai berbagai macam bidang keagamaan.

Peneliti menggunakan empat teknik pengumpulan data yang digunakan. Yang pertama adalah menggunakan teknik observasi ke lokasi penelitian yang bertempat di pondok pesantren G ontor Ponorogo sekaligus peneliti memetakan dan mengi dentifikasi gambaran konsep penerimaan dan penolakan narasi Islamisme di lokasi penelitian. Selama proses observasi berlangsung, peneliti melakukan pengklasifikasian subjek penelitian yang akan di jadikan informan untuk target wawancara (J hon W. Creswell, 2018 : 254). Yang kedua adalah proses wawancara yang dilakukan ol eh peneliti terhadap informan yang telah dipilih dengan panduan proses wawancara (J hon W. Creswell, 2018 : 254). Yang ketiga adalah live story, yang digunakan oleh peneliti untuk mengetahui pengalaman hidup para informan dengan menanyakan beberpa momen penting yang dianggap peneliti dapat dijadikan data untuk menggambarkan narasi penerimaan dan penolakan Islamisme. K emudian yang keempat adalah telaah sumber, yang di dapatkan dari para informan untuk memperjelas konsep penerimaan dan penolakan narasi Islamisme yang bersumber dari bermacammacam dokumen tertulis atau terekam seperti: buku, majalah-majalah tentang pondok, tulisan lepas, pamflet, selebaran, teks ceramah, kaset rekaman dan video yang tentunya semua itu ada kaitannya dengan narasi Islamisme.

\section{PONDOK PESANTREN DALAM BINGKAI POLITIK DAN BUDAYA}

Slogan unik yang sudah mendunia dan mengidentikkan Gontor adalah berdiri diatas dan untuk semua golongan. Gontor sebagai pondok dengan sistem modern memiliki peran utama dalam bermasyarakat yaitu berupaya untuk memperkuat kesadaran dan daya tolak masyarakat terhadap berbagai macam ancaman yang menyerupai radikalisme dan terorisme. B erbagai macam usaha dilakukan terutama berfokus kepada bagaimana mengatasi semua masalah termasuk wilayah internal dan eksternal yang ada hubungannya 
dengan ancaman konsep radikalisme maupun terorisme. Pada tingkat internal organisasi masyarakat sipil mayoritas selalu mengedepankan aliran Islam wasathiyyah, mendefinisikan makna agama yang cenderung lebih toleran, moderat, serta inklusif, tentunya semua itu di bungkus dengan semangat nasionalisme di kalangan M uslim Indonesia (Najib kailani \& Sunarwoto, 2019: 49).

Dengan kompleksitas antara Islam dan konsep negara-bangsa seakanakan sulit untuk menghindari adanya unsur paradoksal yang menyelimuti berbagai aspek kehidupan dalam bernegara di Indonesia. Sistem demokrasi semakin berkembang pesat dan ditandai dengan kebebasan pers, kebebasan berekspresi serta menyampaikan pendapat pribadi atau komunitas. Efek lainnya yang muncul ke permukaan juga dapat membuka lebar pintu kebebasan dan partisipasi politik termasuk transformasi sosial yang bahkan tidak pernah terjadi sebelumnya. Gontor sebagai pondok dengan sistem yang modern selalu aktif dalam mengatasi masalah-masal ah yang bersifat kontemporer di kalangan masyarakat dengan lembaga lembaga atau organisasi yang telah dibentuk. Termasuk dalam mengatasi isu tentang Islamisme yang memiliki tiga unsur penting yang menjadi ciri khas yaitu: aktor, aktivisme, dan ideologi mereka. Pelaku yang terlibat secara langsung dalam semua unsur I slamisme adalah menggunakan agama I slam sebagai identitas utamanya. Ciri khas yang kedua adalah si kap aktivisme mereka yaitu semua aktivitas tindakan yang bernuansa politik dalam menjalankan kepentingan ideologi mereka.

M enurut A dnin A rmas selaku direktur eksekutif INSITS di dalam pengantarnya mengatakan bahwa persoalan mendasar ummat saat ini adalah keliru dalam memandang kehidupan. ${ }^{1}$ Tuhan tidak lagi memiliki peranan penting dengan ciptaann- $\mathrm{N}$ ya sendiri termasuk ranah agama yang mulai dimanfaatkan oleh sejumlah kalangan demi kepentingan-kepentingan tertentu (Islamisme). M anusia sebagai ciptaan Tuhan selalu diidentikkan dengan halhal yang bersifat duniawi termasuk dalam urusan hak dan kewajibannya.

${ }^{1}$ INSISTS atau Institute for the Study of Islamic Thought and Civilizations adalah sebuah lembaga kajian pemikiran dan peradaban Islam di Indonesia. engan keanggotaan kaum intelektual muda muslim yang sebagian besar merupakan murid-murid Syed M uhammad Naquib al-A ttas di ISTA C K uala L umpur M alaysia. M ereka adalah $\mathrm{H}$ amid Fahmy Zarkasyi, A dian Husaini, U gi Suharto, A nis Malik Thoha, M. A rifin Ismail, Syamsuddin A rif, A dnin A rmas, Iskandar A rnel, B aharuddin A bd. Rahman, dan N irwan Syafrin. Kegiatan utamanya adalah edukasi publik, riset ilmiah, publikasi dan konsultasi akademik. 
Definisi kebebasan diliberalkan dengan cara bebas dari segal a macam aturan sang Pencipta. IImu-ilmu agama dimanfaatkan sebagai sarana untuk meraih materi dan profesi dan kepentingan komunitas tertentu dengan membentuk narasi yang diinginkannya (Zarkasyi, $2012: 1$ ).

Dari hasil wawancara dengan beberapa mahasiswa pasca UNIDA Gontor sekaligus menjadi asatidz, mereka tidak setuju dengan konsep Islam Politik atau Islamisme. A lasan mereka adalah karena bertentangan dengan konsep wasathi yah I slam atau orang barat mengatakan Islam moderat. Istilah Islam moderat saja banyak menuai pro dan kontra apalagi Islamisme itu sendiri yang mencangkup militam, radikal isme, ekstrimisme, dan terorisme. Istilah Islam politik diperkirakan memiliki konsep yang sama dengan Islam nusantara yang berujung pada konsep mempolitisasi Islam itu sendiri. ${ }^{2}$ Terminologi Islamisme dari sisi substansi bermasalah sehingga sangat perlu untuk dikaji ulang dengan beberapa alasan yaitu mengaitkan Islam dengan militansi, radikalisme, eksrimisme, dan terorisme, bagaimana mungkin Islam sebagai agama wahyu yang menjunjung tinggi nilai-nilai kemanusiaan dan ketuhanan dikaitkan dengan empat spektrum tersebut.

Pola penolakan terhadap Islamisme mi rip dengan istilah "Islam moderat puritan" (puritanical moderate Islam) yaitu pemikiran dan praktik keislaman yang pada dasarnya bersifat moderat yang diwarnai oleh sejumlah aspek dari ajaran puritan yang menekankan kepada kemurnian aqidah Islam dari keyakinan syirik dan keyakinan yang menodai agama, heterodoks, sesat, dan mengakibatkan pemurtadan, termasuk liberalism, sekularisme, pluralism, (terutama dalam pengertian relativisme agama), di dalamnya juga membicarakan orientasi pola hukum yang lebih disi plin dalam proses ibadah, lebih mengedepankan isu-isu moralitas, menolak pronografi serta pornoaksi, dan perjudian, yang didefinisikan sebagai mungkarat (kemungkaran), juga mengutamakan kepentingan politik umat Islam, dan mendukung pengembangan ekonomi yang berlandaskan kepada hukum syariah lengkap dengan pasar halalnya (M och N ur Ichwan, Nina M ariani Noor, 2019 : 73). Dalam hasil wawancara peneliti menemukan narasi penolakan terhadap konsep Islamisme yang sama dengan penelitian I chwan (2013) sekaligus menjadi wacana keislaman yang digunakan oleh MUI.

Pola lain yang muncul yaitu istilah Islamisasi politik yang memiliki pola yang sama dengan Islamisasi ilmu pengetahuan. Jika Islamisasi ilmu pengetahuan modern memiliki pola mengislamkan sains dengan cara 
menyusun dan membangun ulang (merekonstruksi) dengan memberikan dasardasar dan tujuan-tujuan yang konsisten dengan Islam. M aka Islamisasi politik memiliki peran berusaha menjalankan konsep negara tetapi tidak meninggalkan prinsip-prinsip Islam. Islamisasi politik bukan berarti ingin merobohkan ideologi NKRI, tetapi tetap menerima konsep negara-bangsa NKRI, termasuk ideologi Pancasila hanya saja lebih menggunakan kacamata Islam atau "Islam moderat puritan" (puritanical moderate Islam) dalam menghadapi berbagai masalah kontemporer baik dalam urusan agama, bangsa, dan negara.

Di sisi lain, negara-bangsa dengan sistem demokrasi sekarang ini mulai bermunculan organisasi-organisasi dengan ideologi tertentu yang terkadang pemerintah menggunakan sikap rejeksionisnya dengan alasan menjaga ideologi negara bangsa yaitu Pancasila, UUD 1945, NKRI, dan B hineka Tunggal Ika. Salah satu contoh misalnya ketika muncul isu khilafah yang di khawatirkan akan menggantikan ideologi negara-bangsa. Di sisi lain banyak partai politik yang menggunakan label Islam dalam berkompetisi. Isu-isu semacam ini tidak lepas dari Islam yang dijadikan sebagai lebel untuk kepentingan-kepentingan tertentu. Singkat kata, pemerintah dan organisasi kontra pemerintah sama-sama penggunakan label politiknya. Sikap yang dilakukan Gontor ketika berhadapan dengan isu-isu kontemporer baik interpretasi negara-bangsa yang terlihat kontroversial, termasuk Islam politik dengan berbagai macam idedologi yang menyelimuti adalah semi-rejeksionis dengan kacamata Islamisasi politik. Semi-rejeksionis dengan kacamata Islamisasi politik yang dimaksud adalah tetap menerima Pancasila, UUD 1945, NK RI, dan B hineka T unggal I ka, tetapi bersikap kritis terhadap interpretasi pemerintah yang bersifat kontroversial hanya saja lebih memperjelas dasar dan tujuan-tujuan yang sesuai dengan Islam.

\section{E. SIMPULAN}

Pondok M odern Darussalam Gontor bersikap "Islam moderat puritan" (puritanical moderate Islam) dengan kaca mata Islamisasi politik dalam menghadapi isu-isu kontemporer termasuk Islam politik atau Islamisme yang diselimuti dengan berbagai macam ideologi. Istilah ini memiliki definisi pemikiran dan praktik keislaman yang pada dasarnya bersifat moderat yang diwarnai oleh sejumlah aspek dari ajaran puritan yang menekankan kepada kemurnian aqidah Islam dari keyakinan syirik dan keyakinan yang menodai agama, heterodoks, sesat, dan mengakibatkan pemurtadan, termasuk libe- 
ralisme, sekularisme, pluralisme (terutama dalam pengertian relativisme agama), di dalamnya juga membicarakan orientasi pola hukum yang lebih disiplin dalam proses ibadah, lebih mengedepankan isu-isu moralitas, menolak pronografi serta pornoaksi, dan perjudian, yang didefinisikan sebagai munkara»(kemungkaran), juga mengutamakan kepentingan politik umat Islam, dan mendukung pengembangan ekonomi yang berlandaskan kepada hukum syariah lengkap dengan pasar halalnya. Istilah Islami sasi politik sendiri menjadi ciri khas Pondok M odern Darussalam Gontor Ponorogo dalam berkompetisi dan menyaring ideologi-ideologi Islam politik atau Islamisme yang terdiri dari empat unsur utama yang menyelimuti yaitu: militansi, radikalisme, ekstremisme, dan terorisme. Pondok M odern Darussal am Gontor juga bersi kap semi-rejeksionis terhadap interpretasi pemerintah yang kontroversial tanpa bermaksud ingin mengganti ideologi negara-bangsa yaitu Pancasila, UUD 1945, NK RI, dan B hineka Tunggal I ka dan bersikap rejeksionis terhadap ideologi-idelogi yang bertentangan dengan ajaran Islam.

\section{DAFTAR PUSTAKA}

B asyir, K., 2016. "Ideologi Gerakan Politik Islam di Indonesia”. A /-Tahrir: Jurnal Pemikiran Islam, 16, 339. https://doi.org/10.21154/al-tahrir. v16i2.423

Dale F. Eickelman, James Piscatori, 1996. M uslim Politics. Princeton: Princeton University Press.

Fithriah, N., 2018. "Kepemimpinan Pendidikan Pesantren (Studi Kewibawaan Pada Pondok Pesantren Salafiyah, M odern, dan K ombinasi)". AQ 13. https://doi.org/10.35931/aq.v0i0.17

Iman Fadhilah, Syaifuddin, Retno M awarini, 2016. "Narasi dan Politik Identitas: Pola Penyebaran dan Penerimaan Radikalisme dan Terorisme di J awa Tengah". J urnal SM aRT Studi M asyarakat, Religi dan Tradisi 2.

John W. Creswell, 2018. Research Design: Pendekatan M etode Kualitatif, dan Campuran, 4th ed. Yogyakarta: Pustaka Pelajar.

Kepel, G., 2003. Jihad: The Trail of Political Islam. Cambridge, M ass: B elknap Press, An Imprint of Harvard U niversity Press. 
K holiludin, T., 2016. "Islamisme, Pos-I slamisme dan Islam Sipil: M embaca A rah Baru Gerakan Islam". IQ 3, 52. https://doi.org/10.31942/ iq.v3i1.2460

Moch Nur Ichwan, Nina M ariani Noor, 2019. A rah Baru Majelis Ulama Indonesia (MUI), 1st ed. Yogyakarta: Pusat Pengkajian Islam, Demokrasi, dan Perdamaian (PusPIDeP).

Najib kailani \& Sunarwoto, 2019. Televangelisme Islam dalam lanskap Otoritas K eagamaan B aru, 1st ed. Pusat Pengkajian Islam, D emokrasi, dan Perdamaian (PusPID eP), Y ogyakarta.

N ashir, H., 2002. "Sekuralisme Politik dan Fundamentalisme A gama: K etegangan K reatif Hubungan A gama dan Politik". Unisia 25, 154-163. https://doi.org/10.20885/unisia.vol25.iss45.art3

Noorhaidi Hasan, 2012. Islam Politik di Dunia Kontemporer: Konsep, Genealogi, Teori. Yogyakarta: Sunan Kalijaga Press.

Peter M andaville, 2007. Global Political Islam. London dan New York: Routledge.

Zarkasyi, H.F., 2012. Misykat: Refleksi Tentang Islam, Westernisasi \& Liberalisasi, Cet. 1. ed. Jakarta: Institute for the Study of Islamic Thought and Civilizations. 